\title{
Rypsi- ja soijapuriste puna-apilasäilörehun valkuaistäydennyksenä
}

\author{
Pirjo Pursiainen ${ }^{1}$, Seija Jaakkola ${ }^{1}$, Mikko Tuori ${ }^{2}$, Marketta Rinne ${ }^{2}$ ja Aila Vanhatalo ${ }^{1}$ \\ ${ }^{1)}$ Kotieläintieteen laitos, PL 28,00014 Helsingin yliopisto, etunimi.sukunimi@helsinki.fi \\ ${ }^{2)}$ MTT, Kotieläintuotannon tutkimus, Tervamäentie 179,05840 Hyvinkää, etunimi.sukunimi@mtt.fi
}

\section{Tiivistelmä}

Tutkimuksessa selvitettiin valkuaisrehun määrän ja valkuaislähteen vaikutuksia lypsylehmien rehun syöntiin, maitotuotokseen ja maidon koostumukseen, kun säilörehu oli puhdasta puna-apilaa. Valkuaisrehuina olivat Öpex®-käsitelty rypsipuriste ja soijapuriste, joita lisättiin ohra-kauraseokseen (1:1) siten, että väkirehussa oli raakavalkuaista keskimäärin 145 (taso 1) tai 180 (taso 2) g/kg kuivaainetta (KA). Rypsipuristeen määrä oli 1,5 (R1) tai $3,0(\mathrm{R} 2) \mathrm{kg} / \mathrm{pv}$ ja soijapuristeen määrä sen suuremman valkuaispitoisuuden vuoksi 0,95 (S1) tai 1,9 (S2) $\mathrm{kg} / \mathrm{pv}$. Lehmät saivat väkirehua keskimäärin 10,8 kg/pv. Säilörehu oli esikuivattua, puna-apilan toisesta sadosta pyöröpaalattua rehua, jota lehmät saivat vapaasti. Säilönnälliseltä laadultaan rehu oli melko pitkälle käynyttä, minkä vuoksi sen sokeripitoisuus oli pieni. Rehussa oli myös runsaasti etikkahappoa, mutta ammoniumtypen osuus kokonaistypestä oli pieni. Säilörehun sulavan orgaanisen aineen pitoisuus kuiva-aineessa (in vitro pepsiinisellulaasimenetelmä) oli keskimäärin $608 \mathrm{~g} / \mathrm{kg}$.

Tutkimus tehtiin tasapainotetun $4 \times 4$ latinalaisen neliön mukaisesti ja siinä oli mukana neljä 23 kertaa poikinutta ay-lehmää. Tutkimuksen alkaessa lehmien poikimisesta oli kulunut 76-85 päivää. Lehmät söivät säilörehua rypsiruokinnoilla keskimäärin $13,3 \mathrm{~kg} \mathrm{KA} / \mathrm{pv}$ ja soijaruokinnoilla $13,1 \mathrm{~kg}$ $\mathrm{KA} / \mathrm{pv}$. Valkuaisen määrää lisättäessä säilörehun syönti väheni vaikutuksen ollessa suurempi ruokittaessa rypsiä kuin soijaa ( $-1,0$ vs. $-0,4 \mathrm{~kg} \mathrm{KA} / \mathrm{pv})$, mutta ero ei ollut tilastollisesti merkitsevä. Väkirehun syönnissä ei ollut eroa ruokintojen välillä. Valkuaistason nosto lisäsi lehmien raakavalkuaisen saantia $(\mathrm{P}<0,05)$, mutta ei vaikuttanut ohutsuolesta imeytyvän valkuaisen $(\mathrm{OIV})$ saantiin. Rypsiä syötettäessä lehmät saivat hieman enemmän OIV:a kuin soijaa syötettäessä $(\mathrm{P}<0,10)$. Myös kuitua (NDF) lehmät saivat enemmän, kun valkuaislähteenä oli rypsi verrattuna soijaan $(\mathrm{P}<0,05)$. Lehmien energian saanti väheni numeerisesti, kun rypsin määrää lisättiin, mutta soijan määrää lisättäessä pysyi samana. Rehuannoksen orgaanisen aineen sulavuudessa ei ollut eroa valkuaislähteen eikä valkuaistasojen välillä. Kuidun sulavuus oli rypsillä ruokittaessa parempi kuin soijalla ruokittaessa $(\mathrm{P}<0,05)$. Valkuaistason nosto ei vaikuttanut kuidun sulavuuteen.

Maitotuotos oli keskimäärin 33,1 (R1), 34,2 (R2), 33,4 (S1) ja 33,6 (S2) kg/pv ja energiakorjattu maitotuotos (EKM) 31,3 (R1), 32,9 (R2), 32,3 (S1) ja 31,4 (S2) kg/pv. Valkuaislähde tai valkuaistaso eivät vaikuttaneet merkitsevästi tuotokseen. Rypsi lisäsi $(\mathrm{P}<0,001)$ maidon valkuaispitoisuutta soijaan verrattuna $(31,7$ vs. $30,9 \mathrm{~g} / \mathrm{kg})$. Muutoin ruokinta ei merkitsevästi vaikuttanut maidon koostumukseen tai rasva-, valkuais- ja laktoosituotokseen.

Rypsipuriste osoittautui soijapuristetta paremmaksi valkuaisen lähteeksi myös yksinomaista puna-apilasäilörehua karkearehuna käytettäessä. Aikaisemmista kokeista poiketen ruokinnan valkuaistason nosto rypsin tai soijan avulla ei lisännyt lainkaan säilörehun kuiva-aineen syöntiä. Rypsilisää käytettäessä maidon valkuaispitoisuus oli kuitenkin merkitsevästi suurempi kuin soijalisää käytettäessä. Plasman pienemmät metioniinipitoisuudet soijaruokinnoilla viittaavat siihen, että metioniinin puute saattoi rajoittaa maidontuotantoa soijapuristeruokinnoilla. Tehty koe antoi viitteitä siitä, että runsaasta lisävalkuaisannoksesta ei olisi apilaan perustuvassa ruokinnassa yhtä suurta hyötyä kuin heinäkasviruokinnassa.

Asiasanat: rypsi, soija, lypsylehmä, puna-apilasäilörehu 


\section{Johdanto}

Apilapohjaisen ruokinnan valkuaistäydennyksestä on julkaistu melko vähän tutkimustietoa varsinkin puna-apilasäilörehun ollessa ainoana karkearehuna ruokinnassa. Vanhatalon ja Jaakkolan (2006) kirjallisuusyhteenvedon mukaan heinäkasvi- ja puna-apilasäilörehun seosta käytettäessä valkuaisrehuilla saadut tuotosvasteet ovat olleet likimain samanlaisia kuin puhtaalla heinäkasvisäilörehulla saadut tuotosvasteet. Näissä tutkimuksissa käytetty väkirehumäärä oli kuitenkin melko pieni, alle $10 \mathrm{~kg} / \mathrm{pv}$. Edelleen valkuaistason vaikutusta tutkittiin vain kahdessa kokeessa. Rypsirouheen määrän lisäys kilosta kahteen kiloon lisäsi sekä apilapitoisen säilörehun kuiva-aineen syöntiä että maito- ja valkuaistuotoksia (Heikkilä 2002). Rinteen ym. (2006) kokeessa rypsipuristetäydennys lisäsi maito- ja valkuaistuotoksia kahteen rypsikiloon asti, mutta tuotosvasteet näyttivät pienenevän nostettaessa rypsitaso kahdesta kilosta neljään kiloon. Samassa kokeessa myös soijapuriste lisäsi maito- ja valkuaistuotoksia. Soijalla saadut tuotosvasteet olivat kuitenkin selvästi pienempiä kuin rypsillä saadut vasteet. Valkuaistason nosto rypsiä käyttäen lisäsi jonkin verran säilörehun syöntiä, mutta soijaa käytettäessä säilörehun kuiva-aineen syönti ei lisääntynyt. Aikaisemmissa kokeissa, joissa perusrehuna on ollut heinäkasvinurmesta tehty säilörehu, sekä säilörehun kuiva-aineen syönti että maito- ja valkuaistuotokset ovat lisääntyneet melko suoraviivaisesti suuriakin rypsi- tai soijatasoja käytettäessä (Rinne ym. 1999, Vanhatalo ym. 2004).

Tässä tutkimuksessa selvitettiin rypsi- ja soijapuristeen vaikutuksia lypsylehmien säilörehun syöntiin, rehuannoksen sulavuuteen, maitotuotokseen ja maidon koostumukseen, kun säilörehu oli tehty puhtaasta puna-apilasta. Rypsi- ja soijapuristeita annettiin kahdella eri valkuaistasolla. Tutkimus tehtiin MMM:n Luomututkimusohjelman projektissa 'Puna-apila tehokkaasti luomumaidoksi'.

\section{Aineisto ja menetelmät}

Koerehuina olivat Mildola Oy:n Öpex®-käsitelty rypsipuriste $(\mathrm{R})$ ja soijapuriste $(\mathrm{S})$, joita lisättiin ohra-kauraseokseen (1:1) siten, että molemmista valkuaislähteistä tuli yhtä paljon raakavalkuaista. Rypsipuristeen määrä oli $1,5(\mathrm{R} 1)$ tai $3,0(\mathrm{R} 2) \mathrm{kg} / \mathrm{pv}$ ja soijapuristeen määrä sen suuremman valkuaispitoisuuden vuoksi 0,95 (S1) tai $1,9(\mathrm{~S} 2) \mathrm{kg} / \mathrm{pv}$. Lisäksi rypsiruokinnoilla olleet lehmät saivat kivennäistäydennyksenä niukasti fosforia sisältävää kivennäistä (Tarmo, Melica Finland; Ca 3, P 5, $\mathrm{Mg} 65, \mathrm{Na} 65 \mathrm{~g} / \mathrm{kg}$ ) ja soijaruokinnoilla olleet lehmät runsaammin fosforia sisältävää kivennäisseosta (Tunnutus-Namino, Suomen Rehu Oy; Ca 15, P 30, Mg 100, Na 50 g/kg). Kaikki lehmät saivat myös ruokasuolaa $100 \mathrm{~g} / \mathrm{pv}$. Väkirehun kokonaismäärä oli 10,70-10,95 kg/pv ja se jaettiin kuudessa yhtä suuressa erässä. Säilörehuna tutkimuksessa oli puhtaan puna-apilakasvuston jälkikasvusta tehty rehu. Apila oli säilöttäessä kukintavaiheessa. Kasvusto niitettiin 2.8. niittomurskaimella, esikuivattiin (n. 44 h) ja paalattiin pyöröpaaleihin muurahaishappopohjaista säilöntäainetta (AIV 2 Plus, 5 l/t, Kemira GrowHow) käyttäen. Lehmät saivat säilörehua vapaasti siten, että jäännösrehua oli vähintään $5 \%$ annetusta rehusta. Säilörehua jaettiin kolme kertaa päivässä.

Tutkimus tehtiin Viikin opetus- ja tutkimustilan navetassa talvella 2006 tasapainotetun $4 \times 4$ latinalaisen neliön mukaisesti. Kunkin jakson 12 ensimmäistä päivää olivat valmistuskautta ja koepäivät 13-19 keruukautta. Tutkimuksessa oli mukana neljä 2-3 kertaa poikinutta ay-lehmää. Kokeen alkaessa lehmien poikimisesta oli kulunut 76-85 päivää. Lehmien maitotuotos ennen kokeen alkua oli keskimäärin 43,8 (keskihajonta 5,8) kg päivässä ja elopaino 642 (keskihajonta 52,0) kg.

Syönnin määrittämiseksi rehut ja jäännösrehut punnittiin päivittäin. Keruukauden aikana rehuista kerättiin päivittäin näytettä rehunpunnitusten yhteydessä analyysejä varten. Väkirehuista otetut näytteet yhdistettiin rehuittain yhdeksi koko koeaikaa edustavaksi näytteeksi. Säilörehut analysoitiin jaksoittain. Rehuanalyysien lisäksi säilörehuista määritettiin orgaanisen aineen in vitro sulavuus (pepsiini-sellulaasiliukoisuusmenetelmä) ja sulamattoman kuidun (iNDF) pitoisuus (12 vrk:n nailonpussi-inkubaatio pötsissä).

Maitotuotos mitattiin päivittäin (Tru-Test WB). Jokaisen keruukauden lopussa maidosta otettiin näyte neljältä peräkkäiseltä lypsykerralta. Yhdistetystä näytteestä määritettiin Valion Seinäjoen aluelaboratoriossa rasva-, valkuais-, laktoosi- ja ureapitoisuus infrapuna-analysaattorilla. Lehmät punnittiin ennen kokeen alkua ja jokaisen keruukauden lopussa kahtena peräkkäisenä päivänä. Rehuannoksen sulavuuden määrittämiseksi (AIA merkkiaineena) lehmiltä kerättiin jokaisen jakson lopussa sontanäyte kahdesti päivässä viitenä peräkkäisenä päivänä. Jokaisen jakson viimeisenä päivänä lehmien häntäsuonesta otettiin verinäytteet ennen aamuruokintaa (klo 5) sekä klo 8, 11, 14 ja 17. Verinäyte otettiin häntäsuoneen näytteenottoa edeltävänä iltana asetetusta kanyylistä. 
Plasmanäytteistä määritettiin glukoosi, vapaat rasvahapot (NEFA), insuliini, etikkahappo ja $\beta$ hydroksivoihappo (BHBA). Aminohappojen ja urean pitoisuudet plasmassa määritettiin klo 5 ja 8 yhdistetyistä näytteistä.

Syönti- ja tuotostiedot laskettiin jokaiselta jaksolta koepäivien 13-19 keskiarvotiedoista. Tulokset analysoitiin tilastollisesti SASin Mixed-proseduurilla. Tilastollisessa mallissa olivat mukana jakson, valkuaisrehun ja valkuaistason vaikutukset sekä valkuaisrehun ja valkuaistason yhdysvaikutus. Lehmä oli mallissa satunnaistekijänä. Kokeesta poistettiin 2. jaksolta yhden lehmän syönti- ja tuotostiedot koepäivältä 19 (kipeän jalan vuoksi söi huonosti) ja yhden lehmän maidon laktoosipitoisuus 3. jaksolta poikkeavan pienen pitoisuuden vuoksi.

\section{Tulokset ja niiden tarkastelu}

\section{Rehujen koostumus}

Väkirehuseosten raakavalkuaispitoisuus oli valkuaistasolla 1 keskimäärin $145 \mathrm{~g} / \mathrm{kg} \mathrm{KA}$ ja tasolla 2 keskimäärin $180 \mathrm{~g} / \mathrm{kg} \mathrm{KA}$ (taulukko 1). Väkirehuseoksen OIV-pitoisuus oli rypsiä käytettäessä hieman suurempi kuin soijaa käytettäessä, mikä johtui rypsin suuremmasta annosmäärästä. Rypsipuristeen suuremman kuitupitoisuuden vuoksi rypsiä sisältäneiden väkirehuseosten kuitupitoisuus oli suurempi kuin soijaa sisältäneiden väkirehuseosten. Valkuaistason nosto lisäsi hieman väkirehuseoksen energiapitoisuutta.

Puna-apilan esikuivatus onnistui hieman epävakaasta säästä huolimatta varsin hyvin, sillä kuiva-ainepitoisuus nousi niittovaiheen arvosta $(125 \mathrm{~g} / \mathrm{kg})$ lähes tavoiteltuun $(250 \mathrm{~g} / \mathrm{kg})$. Säilörehu oli kuitenkin melko pitkälle käynyttä, minkä vuoksi sen sokeripitoisuus oli hyvin pieni. Lisäksi rehussa oli runsaasti etikkahappoa. Sen sijaan ammoniumtypen ja liukoisen typen osuus kokonaistypestä oli pieni, mikä todennäköisesti johtui apilan luontaisesti sisältämästä, rehun valkuaisen hajoamista ehkäisevästä polyfenolioksidaasientsyymistä (Jones ym. 1995).

Taulukko 1. Väkirehuseosten, säilörehun raaka-aineen ja säilörehun koostumus sekä rehujen rehuarvot.

\begin{tabular}{|c|c|c|c|c|c|c|}
\hline Koerehu & $\begin{array}{l}\text { Rypsi- } \\
\text { puriste } 1\end{array}$ & $\begin{array}{l}\text { Rypsi- } \\
\text { puriste } 2\end{array}$ & $\begin{array}{l}\text { Soija- } \\
\text { puriste } 1\end{array}$ & $\begin{array}{l}\text { Soija- } \\
\text { puriste } 2\end{array}$ & $\begin{array}{l}\text { Puna-apila } \\
\text { raaka-aine }\end{array}$ & $\begin{array}{l}\text { Puna-apila } \\
\text { säilörehu }\end{array}$ \\
\hline Kuiva-aine (KA), g/kg & 870 & 873 & 861 & 863 & 236 & $270^{\mathrm{a}}$ \\
\hline & & & & & & 4,27 \\
\hline \multicolumn{7}{|l|}{ Koostumus, g/kg KA } \\
\hline Tuhka & 54 & 54 & 55 & 54 & 101 & 100 \\
\hline Raakavalkuainen & 146 & 182 & 143 & 177 & 187 & 188 \\
\hline Kuitu (NDF) & 239 & 257 & 216 & 210 & 418 & 342 \\
\hline iNDF & & & & & & 114 \\
\hline Maitohappo & & & & & & 86 \\
\hline Etikkahappo & & & & & & 41 \\
\hline Voihappo & & & & & & 0,15 \\
\hline Vesiliukoiset hiilihydraatit & & & & & 64 & 4 \\
\hline Etanoli & & & & & & 18 \\
\hline Liukoinen N, g/kg N & & & & & & 450 \\
\hline Ammonium-N, g/kg N & & & & & & 53 \\
\hline Org. aineen sulavuus, $\mathrm{g} / \mathrm{kg}^{\mathrm{b}}$ & & & & & & 676 \\
\hline $\mathrm{D}$-arvo, $\mathrm{g} / \mathrm{kg} \mathrm{KA} \mathrm{c}^{\mathrm{c}}$ & & & & & $629^{\mathrm{d}}$ & $608^{\mathrm{e}}$ \\
\hline $\mathrm{OIV}, \mathrm{g} / \mathrm{kg} \mathrm{KA}$ & 102 & 112 & 99 & 105 & & 84 \\
\hline PVT, g/kg KA & -21 & 3 & -19 & 7 & & 43 \\
\hline $\mathrm{ME}, \mathrm{MJ} / \mathrm{kg} \mathrm{KA}$ & 12,50 & 12,76 & 12,50 & 12,72 & & 9,73 \\
\hline $\mathrm{RY} / \mathrm{kg} \mathrm{KA}$ & 1,068 & 1,090 & 1,069 & 1,088 & & 0,83 \\
\hline Syönti-indeksi ${ }^{\mathrm{f}}$ & & & & & & 82 \\
\hline Syönti-indeksi ${ }^{\mathrm{g}}$ & & & & & & 99 \\
\hline
\end{tabular}

${ }^{a}$ Säilörehun kuiva-ainepitoisuus korjattu Huidan ym. (1986) mukaan; ${ }^{b}$ Orgaanisen aineen sulavuus in vitro (pepsiinisellulaasiliukoisuusmenetelmä); ${ }^{\mathrm{c}}$ Sulavan orgaanisen aineen pitoisuus; ${ }^{\mathrm{d}}$ Valion NIR-määritys, ${ }^{\mathrm{e}}$ Laskettu OA:n in vitro--sulavuudesta. ${ }^{\mathrm{H}}$ Huhtanen ym. (2002); ${ }^{\mathrm{g}}$ Huhtanen ym. (2007). 


\section{Syönti ja ruokinnan sulavuus}

Lehmien säilörehun syönnissä ei ollut merkitsevää eroa rypsiä tai soijaa saaneiden lehmien välillä (taulukko 2). Myöskään valkuaistason nosto ei merkitsevästi vaikuttanut säilörehun syöntiin. Numeerisesti säilörehun syönti kuitenkin hieman väheni rypsiä $(-1,0 \mathrm{~kg} \mathrm{KA} / \mathrm{pv})$ ja soijaa $(-0,4 \mathrm{~kg}$ $\mathrm{KA} / \mathrm{pv}$ ) syötettäessä, kun valkuaisrehun osuutta väkirehuannoksesta lisättiin. Kun Rinteen ym. (2006) kokeessa lehmiä ruokittiin puna-apilapitoisella säilörehulla (50\% säilörehuseoksen kuiva-aineesta), lehmät söivät säilörehua enemmän rypsiä kuin soijaa sisältäneillä ruokinnoilla (13,5 vs. $12,7 \mathrm{~kg}$ $\mathrm{KA} / \mathrm{pv}$ ). Valkuaistason nosto ei Rinteenkään ym. (2006) kokeessa merkitsevästi vaikuttanut säilörehun syöntiin. Numeerisesti säilörehun syönti kuitenkin lisääntyi $0,3 \mathrm{~kg} \mathrm{KA} / \mathrm{pv}$, kun rypsin määrää lisättiin 2 kilosta 4 kiloon ja $0,7 \mathrm{~kg} \mathrm{KA} / \mathrm{pv}$, kun soijan määrä lisääntyi 1,4 kilosta 2,9 kiloon. Sen sijaan heinäkasvisäilörehulla ruokittaessa lehmien säilörehun syönti lisääntyi lineaarisesti, kun ruokinnan valkuaispitoisuutta lisättiin rypsipuristeella tai soijarouheella (Vanhatalo ym. 2004). Suuremmista rypsin kuin soijan määristä johtuen lehmät saivat rypsipuristeruokinnalla enemmän rasvaa kuin soijapuristeruokinnalla. Rypsipuristeeseen sisältyvä rasvalisä oli tässä kokeessa silti suurimmallakin rypsipuristetasolla alle $300 \mathrm{~g} / \mathrm{pv}$. Vastaava valkuaisrehuun sisältyvä rasvalisä ei ole aikaisemmissa tutkimuksissa ollut yhteydessä heinäkasvisäilörehun syöntiin (Rinne ym. 1999, Vanhatalo ym. 2004). Valkuaistason nosto ei vaikuttanut kuidun sulavuuteen tässä kokeessa. Sen sijaan muissa kokeissa valkuaistason nosto on parantanut kuidun sulavuutta (Rinne ym. 1999, Vanhatalo ym. 2004, Rinne ym. 2006).

Valkuaistason nosto lisäsi lehmien raakavalkuaisen saantia $(\mathrm{P}<0,05)$, mutta ei vaikuttanut ohutsuolesta imeytyvän valkuaisen (OIV) saantiin (taulukko 2). Rypsiruokinnoilla lehmät saivat vähän enemmän OIV:a kuin soijaruokinnoilla $(\mathrm{P}<0,1)$. Myös kuitua lehmät saivat enemmän kun valkuaislähteenä oli rypsi verrattuna soijaan $(\mathrm{P}<0,05)$. Valkuaistason noustessa kuidun saanti numeerisesti pienentyi sekä rypsi- että soijaruokinnalla. Lehmien energian saannissa ei ollut tilastollisesti merkitsevää eroa eri ruokintojen välillä. Numeerisesti energian saanti hiukan väheni, kun rypsin osuutta rehuannoksesta lisättiin.

Valkuaisrehu tai valkuaistaso eivät vaikuttaneet rehuannoksen orgaanisen aineen ja raakavalkuaisen sulavuuteen, mutta kuidun sulavuus oli soijalla ruokittaessa huonompi kuin rypsillä ruokittaessa $(\mathrm{P}<0,05)$ (taulukko 2). Yleensä kuitu on ollut huonommin sulavaa rypsi- kuin soijaruokinnoilla (Rinne ym. 2006).

Taulukko 2. Lehmien rehun syönti, ravintoaineiden saanti ja ruokinnan sulavuus.

\begin{tabular}{|c|c|c|c|c|c|c|c|c|}
\hline \multirow{2}{*}{$\begin{array}{l}\text { Valkuaisrehu } \\
\text { Valkuaistaso }\end{array}$} & \multicolumn{2}{|c|}{ Rypsipuriste } & \multicolumn{2}{|c|}{ Soijapuriste } & \multirow[b]{2}{*}{ SEM } & \multicolumn{3}{|c|}{ Tilastollinen merkitsevyys } \\
\hline & 1 & 2 & 1 & 2 & & R vs. $S$ & $\begin{array}{c}\text { Valk.- } \\
\text { taso }\end{array}$ & $\begin{array}{c}\text { Valk.rehu } \times \\
\text { valk.taso }\end{array}$ \\
\hline \multicolumn{9}{|l|}{ Rehun syönti, kg KA/pv } \\
\hline Säilörehu & 13,8 & 12,8 & 13,3 & 12,9 & 0,74 & & & \\
\hline Väkirehu & 9,4 & 9,3 & 9,3 & 9,4 & 0,12 & & & \\
\hline Yhteensä & 23,2 & 22,1 & 22,5 & 22,4 & 0,77 & & & \\
\hline Vr.-osuus, g/kg KA & 409 & 425 & 410 & 423 & 13,4 & & & \\
\hline \multicolumn{9}{|l|}{ Ravintoaineiden saanti } \\
\hline Orgaaninen aine, $\mathrm{kg} / \mathrm{pv}$ & 21,4 & 20,4 & 20,7 & 20,5 & 0,69 & & & \\
\hline Raakavalkuainen, g/pv & 3943 & 4079 & 3814 & 4078 & 138,8 & & $*$ & \\
\hline Kuitu, g/pv & 6947 & 6744 & 6563 & 6396 & 249,8 & * & & \\
\hline $\mathrm{ME}, \mathrm{MJ} / \mathrm{pv}$ & 252 & 244 & 245 & 246 & 7,6 & & & \\
\hline RY, ry/pv & 21,6 & 20,8 & 21,0 & 21,0 & 0,65 & & & \\
\hline $\mathrm{OIV}, \mathrm{g} / \mathrm{pv}$ & 2122 & 2124 & 2031 & 2070 & 64,6 & o & & \\
\hline $\mathrm{PVT}, \mathrm{g} / \mathrm{kg} \mathrm{KA} / \mathrm{pv}$ & 17 & 26 & 18 & 28 & 0,71 & * & $* * *$ & \\
\hline \multicolumn{9}{|l|}{ Sulavuus, $\mathrm{g} / \mathrm{kg}$} \\
\hline Orgaaninen aine & 694 & 695 & 687 & 689 & 9,8 & & & \\
\hline Raakavalkuainen & 666 & 676 & 661 & 671 & 14,3 & & & \\
\hline Kuitu & 429 & 458 & 398 & 398 & 20,0 & $*$ & & \\
\hline
\end{tabular}




\section{Maitotuotos ja maidon koostumus}

Lehmien maitotuoksessa tai EKM-tuotoksessa ei ollut tilastollisesti merkitsevää eroa valkuaislähteen tai valkuaistason välillä (taulukko 3). Valkuaistasoa nostettaessa maito- ja valkuaistuotokset lisääntyivät kuitenkin numeerisesti rypsillä ruokittaessa $(1,1 \mathrm{~kg} / \mathrm{pv}$ ja $42 \mathrm{~g} / \mathrm{pv})$, mutta soijaa syöneiden lehmien tuotokset pysyivät samana. Rypsillä saadut tuotosvasteet olivat samaa luokkaa kuin aikaisemmin puna-apilapitoisella ruokinnalla tehdyssä Rinteen ym. (2006) kokeessa rypsin määrän noustessa kahdesta neljään kiloon. Toisin kuin tässä kokeessa Rinteen ym. (2006) kokeessa saatiin positiivinen tuotosvaste myös soijapuristeelle, joskin selvästi pienempi kuin rypsipuristeelle. Aikaisemmissa kokeissa, joissa perusrehuna on ollut heinäkasvinurmesta tehty säilörehu, sekä maitoettä valkuaistuotokset ovat lisääntyneet melko suoraviivaisesti suuriakin valkuaistasoja käytettäessä (Rinne ym. 1999, Vanhatalo ym. 2004).

Käytetty valkuaisrehu tai valkuaistaso ei vaikuttanut maidon rasvapitoisuuteen, mutta rypsi lisäsi maidon valkuaispitoisuutta merkitsevästi $(\mathrm{P}<0,001)$ soijaan verrattuna $(31,7 \mathrm{vs} .30,9 \mathrm{~g} / \mathrm{kg})$. Plasman kokonaisaminohappojen pitoisuudessa ei ollut eroja rypsi- ja soijaruokintojen välillä, mutta metioniinin pitoisuus oli rypsiruokinnoilla merkitsevästi $(\mathrm{P}<0.05)$ suurempi kuin soijaruokinnoilla (taulukko 4) samoin kuin Rinteen ym. (2006) kokeessa. Tämä viittaa siihen, että metioniinin puute saattoi rajoittaa maidontuotantoa soijaa syötettäessä. Soijapuristeen valkuaisen pötsihajoavuus on ollut todennäköisesti melko suuri. Korhosen ym. (2002) kokeessa soijarouheen valkuaisen in vivo pötsihajoavuus oli $75 \%$. Samoin kuin aikaisemmissa kokeissa (Vanhatalo ym. 2004, Rinne ym. 2006) myös plasman ureapitoisuus oli suurempi soija- kuin rypsipuristeruokinnoilla viitaten huonompaan soijavalkuaisen hyväksikäyttöön. Rehuannoksen raakavalkuaispitoisuuden noususta huolimatta [170 (R1), 185 (R2), 169 (S1), 182 (S2) g/kg KA] maidon ureapitoisuus ja rehutypen hyväksikäyttö maidontuotantoon ei muuttunut rypsin määrää lisättäessä päinvastoin kuin soijalla.

Taulukko 3. Maitotuotos, maidon koostumus ja ravintoaineiden hyväksikäyttö.

\begin{tabular}{|c|c|c|c|c|c|c|c|c|}
\hline \multirow{2}{*}{$\begin{array}{l}\text { Valkuaisrehu } \\
\text { Valkuaistaso }\end{array}$} & \multicolumn{2}{|c|}{ Rypsipuriste } & \multicolumn{2}{|c|}{ Soijapuriste } & \multirow[b]{2}{*}{ SEM } & \multicolumn{3}{|c|}{ Tilastollinen merkitsevyys } \\
\hline & 1 & 2 & 1 & 2 & & $\begin{array}{c}\text { Rypsi } \\
\text { vs. soija }\end{array}$ & $\begin{array}{l}\text { Valk.- } \\
\text { taso }\end{array}$ & $\begin{array}{c}\text { Valk.rehu } \times \\
\text { valk.taso }\end{array}$ \\
\hline \multicolumn{9}{|l|}{ Maidontuotanto } \\
\hline Maito, kg/pv & 33,1 & 34,2 & 33,4 & 33,6 & 1,99 & & & \\
\hline $\mathrm{EKM}, \mathrm{kg} / \mathrm{pv}^{\mathrm{a}}$ & 31,3 & 32,9 & 32,3 & 31,4 & 2,20 & & & \\
\hline Rasva, g/pv & 1245 & 1283 & 1324 & 1248 & 87,9 & & & \\
\hline Valkuainen, g/pv & 1043 & 1085 & 1029 & 1024 & 48,7 & & & \\
\hline Laktoosi, g/pv & 1494 & 1553 & 1520 & 1531 & 117,6 & & & \\
\hline \multicolumn{9}{|l|}{ Maidon koostumus } \\
\hline Rasva, g/kg & 37,3 & 37,6 & 39,5 & 37,4 & 1,70 & & & \\
\hline Valkuainen, g/kg & 31,6 & 31,8 & 31,0 & 30,7 & 0,76 & $* * *$ & & \\
\hline Laktoosi, g/kg & 44,9 & 45,4 & 45,5 & 45,5 & 0,89 & & & \\
\hline Urea, mg/100 ml & 35 & 36 & 35 & 39 & 1,6 & & & \\
\hline Elop. muutos, $\mathrm{kg} / \mathrm{pv}$ & 0,274 & $-0,083$ & 0,084 & 0,012 & 0,1738 & & & \\
\hline Maidon N/rehun N & 25,8 & 26,0 & 26,5 & 24,7 & 1,08 & & & \\
\hline OIV:n hyv.käyttö & 0,668 & 0,688 & 0,699 & 0,676 & 0,0274 & & & \\
\hline OIV/EKM, g/kg ${ }^{\mathrm{c}}$ & 51,1 & 48,9 & 46,4 & 49,0 & 3,15 & & & \\
\hline EKM kg/kg KA & 1,34 & 1,49 & 1,44 & 1,41 & 0,102 & & & \\
\hline
\end{tabular}

${ }^{a}$ Sjaunja ym. (1991); ${ }^{b}$ valkuaistuotos/(OIV:n saanti-OIV ylläpitoon); ${ }^{c}(O I V: n$ saanti-OIV ylläpitoon)/EKM; Tilastollinen merkitsevyys $* * *=p<0,001, * *=p<0,01, *=p<0,05,0=p<0,10$

\section{Johtopäätökset}

Rypsipuriste osoittautui soijapuristetta paremmaksi valkuaisen lähteeksi myös yksinomaista punaapilasäilörehua karkearehuna käytettäessä. Aikaisemmista kokeista poiketen ruokinnan valkuaistason nosto rypsin tai soijan avulla ei lisännyt lainkaan säilörehun kuiva-aineen syöntiä. Rypsipuristelisää käytettäessä maidon valkuaispitoisuus oli kuitenkin merkitsevästi suurempi kuin soijapuristelisää käytettäessä. Plasman pienemmät metioniinipitoisuudet soijaruokinnoilla viittaavat siihen, että metioniinin puute saattoi rajoittaa maidontuotantoa soijapuristeruokinnoilla. Tehty koe antoi viitteitä siitä, että runsaasta lisävalkuaisannoksesta ei olisi apilaan perustuvassa ruokinnassa yhtä suurta hyötyä kuin heinäkasviruokinnassa. 
Taulukko 4. Ravintoaineiden ja aminohappojen pitoisuus plasmassa.

\begin{tabular}{|c|c|c|c|c|c|c|c|c|}
\hline \multirow{2}{*}{$\begin{array}{l}\text { Valkuaisrehu } \\
\text { Valkuaistaso }\end{array}$} & \multicolumn{2}{|c|}{ Rypsipuriste } & \multicolumn{2}{|c|}{ Soijapuriste } & \multirow[b]{2}{*}{ SEM } & \multicolumn{3}{|c|}{ Tilastollinen merkitsevyys } \\
\hline & 1 & 2 & 1 & 2 & & $\begin{array}{c}\text { Rypsi } \\
\text { vs. soija }\end{array}$ & $\begin{array}{c}\text { Valk.- } \\
\text { taso }\end{array}$ & $\begin{array}{c}\text { Valk.rehux } \\
\text { valk.taso }\end{array}$ \\
\hline Glukoosi, mmol/l & 4,23 & 4,18 & 4,14 & 4,06 & 0,144 & & & \\
\hline NEFA, mmol/l & 0,163 & 0,170 & 0,163 & 0,142 & 0,0188 & & & \\
\hline BHBA, mmol/l & 1,18 & 1,25 & 1,34 & 1,25 & 0,097 & & & o \\
\hline Etikkahappo, mmol/1 & 1,97 & 2,06 & 2,02 & 1,99 & 0,144 & & & \\
\hline Insuliini, $\mu \mathrm{mol} / 1$ & 8,95 & 8,13 & 7,17 & 7,12 & 1,007 & $\mathrm{o}$ & & \\
\hline Urea, $\mu \mathrm{mol} / 1$ & 5693 & 6190 & 6196 & 6586 & 217,5 & $\mathrm{o}$ & o & \\
\hline \multicolumn{9}{|l|}{ Aminohapot, $\mu \mathrm{mol} / \mathrm{l}$} \\
\hline Arginiini & 92,3 & 102,3 & 90,3 & 83,6 & 6,05 & & & \\
\hline Histidiini & 62,3 & 67,4 & 59,5 & 66,1 & 3,72 & & & \\
\hline Isoleusiini & 177,0 & 188,6 & 194,1 & 170,5 & 12,21 & & & \\
\hline Leusiini & 195,3 & 218,1 & 203,3 & 196,7 & 11,57 & & & \\
\hline Lysiini & 108,3 & 122,2 & 113,4 & 103,3 & 8,22 & & & \\
\hline Metioniini & 21,6 & 21,2 & 19,3 & 16,1 & 1,37 & $*$ & & \\
\hline Fenyylialaniini & 59,4 & 64,0 & 55,7 & 57,0 & 2,63 & $\mathrm{o}$ & & \\
\hline Treoniini & 118,5 & 129,0 & 113,3 & 111,5 & 7,49 & & & \\
\hline Tryptofaani & 44,8 & 43,3 & 42,4 & 39,1 & 2,25 & & & \\
\hline Valiini & 354,3 & 391,1 & 355,8 & 366,6 & 23,73 & & & \\
\hline Alaniini & 259,9 & 227,1 & 248,8 & 222,9 & 21,20 & & & \\
\hline Asparagiini & 69,8 & 74,3 & 77,4 & 69,1 & 4,80 & & & \\
\hline Aspartaatti & 8,1 & 7,7 & 8,1 & 8,5 & 0,82 & & & \\
\hline Kystiini & 22,7 & 21,2 & 21,6 & 21,5 & 0,98 & & & \\
\hline Glutamiini & 264,2 & 261,8 & 259,6 & 271,8 & 13,04 & & & \\
\hline Glutamaatti & 53,4 & 53,2 & 55,2 & 52,7 & 4,18 & & & \\
\hline Glysiini & 330,5 & 313,3 & 319,8 & 317,8 & 17,23 & & & \\
\hline Proliini & 114,8 & 102,0 & 119,4 & 113,1 & 9,56 & & & \\
\hline Seriini & 97,8 & 97,2 & 102,2 & 98,0 & 6,15 & & & \\
\hline Tyrosiini & 60,5 & 62,6 & 53,4 & 56,7 & 4,65 & & & \\
\hline Haaraketjuiset $^{\mathrm{a}}$ & 726,6 & 797,8 & 753,2 & 733,8 & 43,83 & & & \\
\hline Välttämättömät ${ }^{\mathrm{b}}$ & 1234 & 1347 & 1247 & 1211 & 64,8 & & & \\
\hline Ei-välttämättömät ${ }^{\mathrm{c}}$ & 1282 & 1220 & 1266 & 1232 & 61,9 & & & \\
\hline Yhteensä $^{\mathrm{d}}$ & 2515 & 2567 & 2513 & 2443 & 109,8 & & & \\
\hline
\end{tabular}

\section{Kirjallisuus}

Heikkilä, T. 2002. Yksivuotinen raiheinäsäilörehu maidontuotannossa. Maataloustieteen Päivät 2002. Kotieläintiede. Maaseutukeskusten Liiton julkaisuja nro 977. p. 147-150.

Huhtanen, P., Khalili, H., Nousiainen, J.I., Rinne, M., Jaakkola, S., Heikkilä, T. \& Nousiainen, J. 2002. Prediction of the relative intake potential of grass silage by dairy cows. Livestock Production Science 73: 111130.

Huhtanen, P., Rinne, M. \& Nousiainen, J. 2007. Evaluation of the factors affecting silage intake of dairy cows: a revision of the relative silage dry-matter intake index. Animal 1: 758-770.

Huida, L., Väätäinen, H. \& Lampila, M. 1986. Comparison of dry matter contents in grass silages as determined by oven drying and gas chromatographic water analyses. Annales Agriculturae Fenniae 25: 215-230.

Jones, B.A., Muck, R.E. \& Hatfield R.D. 1995. Red clover extract inhibits legume proteolysis. Journal of Science of Food and Agriculture 67: 329-333.

Rinne, M., Jaakkola, S., Varvikko, T. \& Huhtanen, P. 1999. Effects of the type and amount of rapeseed feed on milk production. Acta Agriculturae Scandinavica, Section A Animal Science 49: 137-148.

Rinne, M., Kuoppala, K., Ahvenjärvi, S. \& Vanhatalo, A. 2006. Rypsi soijaa parempi lypsylehmien valkuaistäydennys myös apilapitoista rehua syötettäessä. Julkaisussa:Maataloustieteen Päivät 2006 [verkkojulkaisu]. Suomen Maataloustieteellisen Seuran julkaisuja no 21. Toim. Anneli Hopponen. 
Viitattu [11.6.2007]. Julkaistu 9.1.2006. Saatavilla Internetissä: http://www.smts.fi/esit06/1002.pdf. ISBN 9519041-49-4.

Sjaunja, L.O., Baevre, L., Junkkarinen, L., Pedersen, J. \& Setälä, J. 1991. A Nordic proposal for an energy corrected milk (ECM) formula. In: Gaillon, P. \& Chabert, Y. (eds.). Performance recording of animals: State of the art 1990. EAAP Publication no. 50, PUDOC, Wageningen, the Netherlands. p. 156-157.

Vanhatalo, A. \& Jaakkola, S. 2006. Onko puna-apilassa potentiaalia? Julkaisussa: Maataloustieteen Päivät 2006[verkkojulkaisu]. Suomen Maataloustieteellisen Seuran julkaisuja no 21. Toim. Anneli Hopponen. Viitattu [31.7.2007]. Julkaistu 9.1.2006. Saatavilla Internetissä: http://www.smts.fi/esit06/1004.pdf. ISBN 951-9041-494.

Vanhatalo, A., Shingfield, K., Pahkala, E., Salo-Väänänen, P., Korhonen, H., Piironen, V. \& Huhtanen, P. 2004. Rypsi ja soija lypsylehmien valkuaislähteenä. Julkaisussa: Maataloustieteen päivät 2004 [verkkojulkaisu]. Suomen Maataloustieteellisen Seuran julkaisuja no 19. Toim. Anneli Hopponen ja Marketta Rinne. Viitattu [8.7.2007]. Julkaistu 5.1.2004. Saatavilla Internetissä: http://www.smts.fi/MTP\%20julkaisu\%202004/esi04/ma03.pdf. ISBN 951-9041-47-8. 